Prepared for the U.S. Department of Energy

under Contract DE-AC05-76RL01830

\title{
Building Technologies Residential Survey
}

TJ Secrest

November 2005

Pacific Northwest NATIONAL LABORATORY

Proudly Operated by Battelle Since 1965 


\title{
DISCLAIMER
}

This report was prepared as an account of work sponsored by an agency of the United States Government. Neither the United States Government nor any agency thereof, nor Battelle Memorial Institute, nor any of their employees, makes any warranty, express or implied, or assumes any legal liability or responsibility for the accuracy, completeness, or usefulness of any information, apparatus, product, or process disclosed, or represents that its use would not infringe privately owned rights. Reference herein to any specific commercial product, process, or service by trade name, trademark, manufacturer, or otherwise does not necessarily constitute or imply its endorsement, recommendation, or favoring by the United States Government or any agency thereof, or Battelle Memorial Institute. The views and opinions of authors expressed herein do not necessarily state or reflect those of the United States Government or any agency thereof.

\author{
PACIFIC NORTHWEST NATIONAL LABORATORY \\ operated by \\ BATTELLE \\ for the \\ UNITED STATES DEPARTMENT OF ENERGY \\ under Contract DE-AC05-76RL01830
}

Printed in the United States of America
Available to DOE and DOE contractors from the Office of Scientific and Technical Information,
P.O. Box 62, Oak Ridge, TN 37831-0062;
ph: (865) 576-8401
fax: $(865)$ 576-5728
email: reports@adonis.osti.gov

\begin{abstract}
Available to the public from the National Technical Information Service, U.S. Department of Commerce, 5285 Port Royal Rd., Springfield, VA 22161 ph: (800) 553-6847 fax: $(703) 605-6900$ email: orders@ntis.fedworld.gov online ordering: http://www.ntis.gov/ordering.htm
\end{abstract}

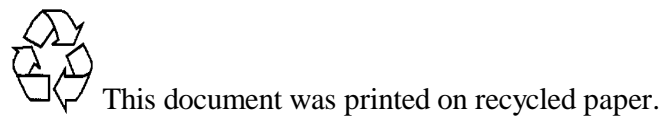




\title{
Building Technologies Residential Survey
}

\author{
Letter Report
}

\section{Tom Secrest}

Pacific Northwest National Laboratory

November 7, 2005 


\section{Introduction}

A telephone survey of 1,025 residential occupants was administered in late October for the Building Technologies Program (BT) to gather information on residential occupant attitudes, behaviors, knowledge, and perceptions.

The next section, Survey Results, provides an overview of the responses, with major implications and caveats.

Additional information is provided in three appendices as follows:

- Appendix A -- Summary Response: Provides summary tabular data for the 13 questions that, with subparts, comprise a total of 25 questions.

- Appendix B -- Benchmark Data: Provides a benchmark by six categories to the 2001 Residential Energy Consumption Survey administered by EIA. These were ownership, heating fuel, geographic location, race, household size and income.

- Appendix C -- Background on Survey Method: Provides the reader with an understanding of the survey process and interpretation of the results.

\section{Survey Results}

First, to better understand the validity of the results, the survey demographics were benchmarked to the 2001 Residential Energy Consumption Survey administered by EIA for six categories - Own/Rent, Heating Fuel, Geographic Location, Race, Household Size, and Income. There was reasonable congruity between the two surveys except for the heating fuel and income categories. In the case of heating fuel where the discrepancy was primarily between natural gas and electric heat, PNNL surmises that the respondent was not sure whether the question pertained to heating fuel or all energy. In the case of household income, the discrepancy was primarily in the lower two income brackets, so that the survey data, when adjusted by the 'Do not Know / Did not Respond' responses, was closer to the EIA data.

The major findings by response and message/implications are:

- Residence Tenure

- $60 \%$ of respondents intend to live in their current dwelling more than 5 years, with owners showing a much higher response (77\%) than renters (24\%), and only $16 \%$ intend to live in their current dwelling 2-5 years.

- It would be expected that behavioral actions would apply to all three residence categories of both owners and renters, low-cost actions would apply to the mid-category of owners and a segment of the renters, and investment actions would only apply to owners responding that they intended to live in the dwelling for more than 5 years.

- Heat Cost

- $64 \%$ of respondents were able to provide an estimate of their monthly heating cost, with a higher proportion of owners $(74 \%)$ than renters $(44 \%)$ responding 'yes.' 
- The estimated costs covered a broad range of variables that reflect differences that include climate, fuel, fuel cost, thermal integrity, and behavior.

- We surmise that many of the responses were for total energy rather than heating energy.

- Even with the above two considerations, the awareness of fuel costs should provide some insight into the valuation/discount process covered in a later question.

- Heating Fuel Type

- About $50 \%$ of both owners and renters responded that they heat with electricity, decreasing to $28 \%$ for natural gas, with a higher share of renters (36\%) using natural gas than owners $(25 \%)$. Owners reported using higher shares of oil, wood, and other fuels than renters.

- The shares of electricity and natural gas are reversed in the EIA benchmark, which begets the suspicion that many of the responses were for the energy form (electricity) that the respondent was most familiar with.

- Knowledge/Perception of Reason(s) for Energy Use

- About $75 \%$ of respondents were aware that heating systems, insulation, weatherization, and/or leaky ducts contributed to their heating costs.

- This awareness, coupled with the relatively high knowledge of heating costs, should help provide some insight into the valuation/discount process covered in a later question.

\section{Survey Applications}

This survey has multiple applications to the BT program:

- First, is the informational value and baseline of residential occupant attitudes, behaviors, knowledge, and perceptions.

- $\quad$ Second is the value provided for the development and targeting of implementation plans for research programs.

- Third is the value provided to the market transformation and Energy Star@ programs to target activities.

- Behavioral Actions

- Many respondents planned on taking one or more of 11 categories of behavioral actions during the upcoming heating season to reduce their heating bill, ranging from a high of $84 \%$ for turning off lights and appliances not in use, to a low of $36 \%$ for turning off power strips for home electronics (question 6 in Appendix A contains a full list of the 11 behavioral measures).

- The good news in this is that behavioral actions, at least as stated by respondents, will be taken over $50 \%$ of the time for energy consuming uses; the bad news is that the percentage taking behavioral actions is not uniformly above $75 \%$ for the 11 categories. 
- Low-Cost Actions

- The share of consumers planning to take a low-cost action this heating season was lower than the share that did not plan to take this action in 5 of the 6 cases - the exception was to have a furnace check-up and filter replacement. At the same time, about $50 \%$ of respondents claim to have taken one or more of the 6 actions (question 7 in Appendix A contains a full list of the 6 low-cost measures).

- In follow-up to the above finding was the high share of respondents that did not plan on taking one or more of the 6 low-cost actions, with having a home energy audit topping the list at $67 \%$, installing a programmable thermostat at $46 \%$, and caulking and weather stripping at $30 \%$.

- Investment Actions

- For the 6 investment actions provided, the share of respondents saying they had or planned to take the action was over 35\% in 4 cases (purchase insulation, Energy Star@ rated windows, Energy Star@ rated light bulbs, and Energy Star@ rated appliances) and nearly $30 \%$ in a fifth (purchase new heating system) (question 8 in Appendix A contains a full list of the 6 investment measures).

- A disappointment was that for over $45 \%$ in all cases, (65\% in 4 cases), respondents said they did not plan on taking the action. This finding lends support to the case for a high discount rate for higher cost actions.

- Behavior and Buying Habits

- $72 \%$ and $52 \%$ of respondents reported that the current discussion in the media about high energy prices affected their behavior and buying, respectively.

- These percentages are higher than the low-cost and investment actions above, suggesting that the respondents have adjusted their behavior and buying habits for non-energy goods and services, that the energy prices are not sufficiently high to overcome their discount rate with respect to energy purchases, or that they don't believe that energy prices will remain at a high level.

- Fuel or Heat Cost

- Nearly 50\% of respondents were more concerned about the cost of fuel for their vehicle rather than home heat, and nearly $50 \%$ thought they had more control over reducing their home heat than their fuel cost.

- An explanation is that the cost of vehicle fuel is more visible as vehicles are typically fueled more than once a month and the fueling process requires an active act (i.e. going to a retail outlet rather than having a good delivered). Also, one is aware of the cost of gasoline, but is not aware the cost for space heat, which can only be determined with analysis unless the fuel is used only for space heat.

- Willingness-to-Pay for \$100 Annual Payback

- When asked how much they would be willing to pay to obtain a $\$ 100$ annual reduction in fuel bill, $24 \%$ responded $\$ 100$ or less, $40 \%$ didn't know or wouldn't make the investment, and remaining $24 \%$ split their response over 6 ranges with the highest at 8\% (\$500-749).

- The $64 \%$ that would not make the investment or only make it if it were equal to or less than the annual return, indicates a very high discount rate to investing in home heating. Conversely, the $24 \%$ 
that would pay to reduce their energy bill ranged from a simple payback of 1-to-2 years to over 20 years.

- The more detailed data did not show a significant difference in the response by other characteristics such as income or education, but surprisingly showed a slight decline in willingness to pay with an increase in age.

- The last two findings indicate a very high discount rate to investing in home heating that may be very difficult to overcome.

- Three Year Payback

- When asked about a three year payback for a $\$ 1,500$ investment, nearly $50 \%$ of the respondents said they were very likely to make the investment, $17 \%$ were neutral to unlikely, and over 35\% were very unlikely or didn't know.

- In comparison, in the previous willingness-topay question, $36 \%$ of the respondents were willing to pay up to $\$ 299$ for a $\$ 100$ annual return. The difference in response may reflect the different way that the payback information was communicated.

- In either case, whether the payback question was asked indirectly or directly, the responses indicate that no more than $50 \%$ would make the investment.

\section{Potential Policy Implication}

Two categories of responses may have implications for policy recommendations to improve residential energy efficiency. These responses pertain to measures that are either low-cost or require an investment, and to the two payback questions.

- First is the low percentage of responders that have had home energy audits and follow-up implementation of recommendations. Many of which, are low-cost weatherization measures that, according to results from the WAP program, provide average energy savings of $23 \%$ worth over $\$ 400$ annually to the homeowner.

- Second is the more than $50 \%$ of responders who reported they would not consider investing in measures that would provide a payback of less than three years.

In both cases, a tax deduction or credit, or a rebate may be necessary to increase the participation of these two groups. A subsequent survey may help to answer this question. 


\section{Appendix A -- Summary Response}

The following 13 questions provide information on the respondents attitudes, behaviors, knowledge, and perceptions. These questions include subparts that effectively increase the number of questions to 25 .

1. Do you own or rent the dwelling in which you live?

\begin{tabular}{|l|c|}
\hline \multicolumn{2}{|c|}{ Response } \\
\hline Own & $69 \%$ \\
\hline Rent & $27 \%$ \\
\hline Not Reported & $5 \%$ \\
\hline Total & $100 \%$ \\
\hline
\end{tabular}

Total may not equal $100 \%$ due to rounding error

2. Which of the following choices best describes about how long you plan to live in your current home.

\begin{tabular}{|l||c||c||c|}
\hline Response & Total & Own & Rent \\
\hline Less than 2 years & $21 \%$ & $8 \%$ & $53 \%$ \\
\hline About 2-5 years & $16 \%$ & $13 \%$ & $20 \%$ \\
\hline More than 5 years & $60 \%$ & $77 \%$ & $24 \%$ \\
\hline Don't Know & $3 \%$ & $2 \%$ & $3 \%$ \\
\hline Total & $100 \%$ & $100 \%$ & $100 \%$ \\
\hline
\end{tabular}

Total may not equal $100 \%$ due to rounding error

3a. Do you know the approximate cost of heating your home?

\begin{tabular}{|l||c||c||c||}
\hline Response & Total & Own & Rent \\
\hline Yes & $64 \%$ & $74 \%$ & $44 \%$ \\
\hline No & $31 \%$ & $22 \%$ & $50 \%$ \\
\hline Don't Know & $5 \%$ & $4 \%$ & $7 \%$ \\
\hline Total & $100 \%$ & $100 \%$ & $100 \%$ \\
\hline
\end{tabular}

Total may not equal $100 \%$ due to rounding error

If YES, read question 3b. If not skip to question 4. 
3b. Could you provide a rough estimate of approximately how much it costs to heat your home per month (applies to the yes responses in 3a)?

\begin{tabular}{|l||c||c||c||}
\hline Response & Total & Own & Rent \\
\hline Less Than $\$ 50$ & $9 \%$ & $5 \%$ & $24 \%$ \\
\hline$\$ 50-74$ & $11 \%$ & $10 \%$ & $17 \%$ \\
\hline$\$ 75-99$ & $8 \%$ & $9 \%$ & $6 \%$ \\
\hline$\$ 100-124$ & $19 \%$ & $21 \%$ & $10 \%$ \\
\hline$\$ 125-149$ & $8 \%$ & $9 \%$ & $6 \%$ \\
\hline$\$ 150-199$ & $15 \%$ & $16 \%$ & $9 \%$ \\
\hline$\$ 200-249$ & $14 \%$ & $15 \%$ & $6 \%$ \\
\hline$\$ 250-299$ & $6 \%$ & $4 \%$ & $12 \%$ \\
\hline$\$ 300-349$ & $3 \%$ & $4 \%$ & $1 \%$ \\
\hline$\$ 350$ or More & $6 \%$ & $6 \%$ & $7 \%$ \\
\hline Don't Know & $2 \%$ & $2 \%$ & $1 \%$ \\
\hline Total & $100 \%$ & $100 \%$ & $100 \%$ \\
\hline
\end{tabular}

Total may not equal $100 \%$ due to rounding error

4. Do you primarily heat your home with electric heat, natural gas, oil, wood burning, or a combination?

\begin{tabular}{|l||c||c||c||}
\hline Response & Total & Own & Rent \\
\hline Electricity & $50 \%$ & $52 \%$ & $49 \%$ \\
\hline Natural Gas & $28 \%$ & $25 \%$ & $36 \%$ \\
\hline Oil & $7 \%$ & $8 \%$ & $5 \%$ \\
\hline Wood & $3 \%$ & $4 \%$ & $1 \%$ \\
\hline Some Combination & $11 \%$ & $13 \%$ & $8 \%$ \\
\hline Other & $3 \%$ & $3 \%$ & $2 \%$ \\
\hline Don't know & $1 \%$ & -- & $3 \%$ \\
\hline Total & $*$ & $*$ & $*$ \\
\hline
\end{tabular}

*Total does not equal $100 \%$ as multiple fuels may be used. 
5. Which of the following do you think might contribute to your heating bill.

\begin{tabular}{|c|c|c|c|}
\hline Response Category & Total & Own & Rent \\
\hline Old or poorly operating heating equipment & $23 \%$ & $19 \%$ & $33 \%$ \\
\hline Cold drafts through cracks and leaks & $38 \%$ & $34 \%$ & $45 \%$ \\
\hline Old or inefficient windows & $37 \%$ & $35 \%$ & $44 \%$ \\
\hline Not enough insulation in the walls and/or roof & $35 \%$ & $34 \%$ & $40 \%$ \\
\hline Leaky heating ducts & $16 \%$ & $15 \%$ & $19 \%$ \\
\hline $\begin{array}{l}\text { Not turning down the thermostat at night or } \\
\text { when no one is home. }\end{array}$ & $37 \%$ & $35 \%$ & $40 \%$ \\
\hline Don't Know or None of These & $26 \%$ & $27 \%$ & $23 \%$ \\
\hline Total & $*$ & $*$ & $*$ \\
\hline
\end{tabular}

*Total does not equal $100 \%$ as multiple responses may apply.

6. Do you plan on taking these behavioral actions during the upcoming heating season to reduce your heating bill.

\begin{tabular}{|c|c|c|c|}
\hline Response Category - Behavioral Action & Total & Own & Rent \\
\hline $\begin{array}{l}\text { Turn down thermostat at night and during unoccupied } \\
\text { periods }\end{array}$ & $72 \%$ & $75 \%$ & $67 \%$ \\
\hline $\begin{array}{l}\text { Use the air dry feature of your dishwasher instead of the } \\
\text { heated drying cycle. }\end{array}$ & $38 \%$ & $40 \%$ & $35 \%$ \\
\hline $\begin{array}{l}\text { Use the Energy } \text { Star }^{\odot} \text { power management features to turn } \\
\text { off your computer and monitor when not in use. }\end{array}$ & $53 \%$ & $54 \%$ & $54 \%$ \\
\hline $\begin{array}{l}\text { Plug home electronics, such as TVs and DVD players, } \\
\text { into power strips; turn the power strips off when the } \\
\text { equipment is not in use }\end{array}$ & $36 \%$ & $35 \%$ & $41 \%$ \\
\hline Lower the thermostat on your hot water heater to $120^{\circ} \mathrm{F}$ & $48 \%$ & $52 \%$ & $39 \%$ \\
\hline Take short showers instead of baths & $61 \%$ & $61 \%$ & $61 \%$ \\
\hline Wash only full loads of dishes and clothes & $74 \%$ & $78 \%$ & $67 \%$ \\
\hline $\begin{array}{l}\text { Use energy-saving settings on refrigerators, dishwashers, } \\
\text { washing machines, and clothes dryers }\end{array}$ & $62 \%$ & $64 \%$ & $59 \%$ \\
\hline Turn off lights and appliances when not in use & $84 \%$ & $86 \%$ & $80 \%$ \\
\hline Decrease or eliminate holiday lighting & $42 \%$ & $40 \%$ & $45 \%$ \\
\hline Reduce heating in seldom used portions of your house & $56 \%$ & $59 \%$ & $47 \%$ \\
\hline Don't Know or None of These & $6 \%$ & $5 \%$ & $9 \%$ \\
\hline Total & $*$ & $*$ & $*$ \\
\hline
\end{tabular}

*Total does not equal $100 \%$ as multiple responses may apply. 
7. Do you plan on taking one or more of these low-cost actions during the upcoming heating season to reduce your heating bill?

7a. Complete an energy audit of your home with the serving utility or an energy agency

\begin{tabular}{|c|c|c|c|}
\hline Response - Low-Cost Action & Total & Own & Rent \\
\hline Plan on taking during the upcoming heating season & $15 \%$ & $12 \%$ & $18 \%$ \\
\hline Have already taken this action & $16 \%$ & $16 \%$ & $15 \%$ \\
\hline Do not plan to take this action & $67 \%$ & $69 \%$ & $62 \%$ \\
\hline Don't know & $3 \%$ & $2 \%$ & $5 \%$ \\
\hline Total & $100 \%$ & $100 \%$ & $100 \%$ \\
\hline
\end{tabular}

Total may not equal $100 \%$ due to rounding error

7b. Have a furnace check-up and regular filter replacement

\begin{tabular}{|c|c|c|c|}
\hline Response - Low-Cost Action & Total & Own & Rent \\
\hline Plan on taking during the upcoming heating season & $23 \%$ & $23 \%$ & $22 \%$ \\
\hline Have already taken this action & $57 \%$ & $61 \%$ & $47 \%$ \\
\hline Do not plan to take this action & $17 \%$ & $13 \%$ & $26 \%$ \\
\hline Don't know & $3 \%$ & $2 \%$ & $5 \%$ \\
\hline Total & $100 \%$ & $100 \%$ & $100 \%$ \\
\hline
\end{tabular}

Total may not equal $100 \%$ due to rounding error

7c. Install storm windows

\begin{tabular}{|c|c|c|c|}
\hline Response - Low-Cost Action & Total & Own & Rent \\
\hline Plan on taking during the upcoming heating season & $9 \%$ & $6 \%$ & $17 \%$ \\
\hline Have already taken this action & $45 \%$ & $53 \%$ & $25 \%$ \\
\hline Do not plan to take this action & $43 \%$ & $40 \%$ & $51 \%$ \\
\hline Don't know & $3 \%$ & $1 \%$ & $6 \%$ \\
\hline Total & $100 \%$ & $100 \%$ & $100 \%$ \\
\hline
\end{tabular}

Total may not equal $100 \%$ due to rounding error

7d. Caulk and weather-strip to reduce leaks

\begin{tabular}{|c|c|c|c|}
\hline Response - Low-Cost Action & Total & Own & Rent \\
\hline Plan on taking during the upcoming heating season & $23 \%$ & $23 \%$ & $22 \%$ \\
\hline Have already taken this action & $45 \%$ & $50 \%$ & $35 \%$ \\
\hline Do not plan to take this action & $30 \%$ & $27 \%$ & $37 \%$ \\
\hline Don't know & $2 \%$ & $1 \%$ & $5 \%$ \\
\hline Total & $100 \%$ & $100 \%$ & $100 \%$ \\
\hline
\end{tabular}

Total may not equal $100 \%$ due to rounding error

7e. Install a programmable furnace thermostat 


\begin{tabular}{|c|c|c|c|}
\hline Response - Low-Cost Action & Total & Own & Rent \\
\hline Plan on taking during the upcoming heating season & $10 \%$ & $9 \%$ & $13 \%$ \\
\hline Have already taken this action & $39 \%$ & $47 \%$ & $23 \%$ \\
\hline Do not plan to take this action & $46 \%$ & $41 \%$ & $57 \%$ \\
\hline Don't know & $5 \%$ & $3 \%$ & $7 \%$ \\
\hline Total & $100 \%$ & $100 \%$ & $100 \%$ \\
\hline
\end{tabular}

Total may not equal $100 \%$ due to rounding error

7f. Program the thermostat to save energy

\begin{tabular}{|c|c|c|c|}
\hline Response - Low-Cost Action & Total & Own & Rent \\
\hline Plan on taking during the upcoming heating season & $19 \%$ & $17 \%$ & $21 \%$ \\
\hline Have already taken this action & $48 \%$ & $53 \%$ & $38 \%$ \\
\hline Do not plan to take this action & $30 \%$ & $27 \%$ & $36 \%$ \\
\hline Don't know & $3 \%$ & $3 \%$ & $5 \%$ \\
\hline Total & $100 \%$ & $100 \%$ & $100 \%$ \\
\hline
\end{tabular}

Total may not equal $100 \%$ due to rounding error

8. Do you plan on taking one or more of these investment actions during the upcoming heating season to reduce your heating bill?

8a. Purchase a new heating system

\begin{tabular}{|c|c|c|c|}
\hline Response - Investment Action & Total & Own & Rent \\
\hline Plan on taking during the upcoming heating season & $8 \%$ & $7 \%$ & $10 \%$ \\
\hline Have already taken this action & $20 \%$ & $25 \%$ & $10 \%$ \\
\hline Do not plan to take this action & $69 \%$ & $67 \%$ & $75 \%$ \\
\hline Don't know & $2 \%$ & $1 \%$ & $6 \%$ \\
\hline Total & $100 \%$ & $100 \%$ & $100 \%$ \\
\hline
\end{tabular}

Total may not equal $100 \%$ due to rounding error

8 b. Increase wall and/or attic insulation

\begin{tabular}{|c|c|c|c|}
\hline Response - Investment Action & Total & Own & Rent \\
\hline Plan on taking during the upcoming heating season & $13 \%$ & $13 \%$ & $12 \%$ \\
\hline Have already taken this action & $24 \%$ & $29 \%$ & $13 \%$ \\
\hline Do not plan to take this action & $61 \%$ & $58 \%$ & $71 \%$ \\
\hline Don't know & $2 \%$ & $1 \%$ & $5 \%$ \\
\hline Total & $100 \%$ & $100 \%$ & $100 \%$ \\
\hline
\end{tabular}

Total may not equal $100 \%$ due to rounding error

8c. Install new Energy Star rated windows 


\begin{tabular}{|c|c|c|c|}
\hline Response - Investment Action & Total & Own & Rent \\
\hline Plan on taking during the upcoming heating season & $10 \%$ & $9 \%$ & $13 \%$ \\
\hline Have already taken this action & $25 \%$ & $30 \%$ & $14 \%$ \\
\hline Do not plan to take this action & $62 \%$ & $60 \%$ & $66 \%$ \\
\hline Don't know & $3 \%$ & $1 \%$ & $6 \%$ \\
\hline Total & $100 \%$ & $100 \%$ & $100 \%$ \\
\hline
\end{tabular}

Total may not equal $100 \%$ due to rounding error

8d. Purchase compact Energy Star fluorescent light bulbs

\begin{tabular}{|l|c||c||c||}
\hline Response - Investment Action & Total & Own & Rent \\
\hline Plan on taking during the upcoming heating season & $18 \%$ & $17 \%$ & $22 \%$ \\
\hline Have already taken this action & $34 \%$ & $38 \%$ & $25 \%$ \\
\hline Do not plan to take this action & $45 \%$ & $43 \%$ & $48 \%$ \\
\hline Don't know & $3 \%$ & $3 \%$ & $5 \%$ \\
\hline Total & $100 \%$ & $100 \%$ & $100 \%$ \\
\hline
\end{tabular}

Total may not equal $100 \%$ due to rounding error

8e. Purchase Energy Star labeled appliances and products to replace aging appliances

\begin{tabular}{|c|c|c|c|}
\hline Response - Investment Action & Total & Own & Rent \\
\hline Plan on taking during the upcoming heating season & $20 \%$ & $19 \%$ & $22 \%$ \\
\hline Have already taken this action & $32 \%$ & $37 \%$ & $23 \%$ \\
\hline Do not plan to take this action & $45 \%$ & $43 \%$ & $51 \%$ \\
\hline Don't know & $3 \%$ & $2 \%$ & $5 \%$ \\
\hline Total & $100 \%$ & $100 \%$ & $100 \%$ \\
\hline
\end{tabular}

Total may not equal $100 \%$ due to rounding error

8f. Refinance your home to purchase energy saving features and/or appliances

\begin{tabular}{|c|c|c|c|}
\hline Response - Investment Action & Total & Own & Rent \\
\hline Plan on taking during the upcoming heating season & $6 \%$ & $5 \%$ & $9 \%$ \\
\hline Have already taken this action & $6 \%$ & $7 \%$ & $5 \%$ \\
\hline Do not plan to take this action & $85 \%$ & $88 \%$ & $81 \%$ \\
\hline Don't know & $3 \%$ & $1 \%$ & $5 \%$ \\
\hline Total & $100 \%$ & $100 \%$ & $100 \%$ \\
\hline
\end{tabular}

Total may not equal $100 \%$ due to rounding error 
9a. Has the current discussion about energy prices influenced your behavior, for example, do you drive less or turn down your thermostat more?

\begin{tabular}{|l||c||c||c||}
\hline Response -- Behavior & Total & Own & Rent \\
\hline Yes & $72 \%$ & $74 \%$ & $68 \%$ \\
\hline No & $27 \%$ & $25 \%$ & $32 \%$ \\
\hline Don't Know & $1 \%$ & $1 \%$ & $1 \%$ \\
\hline Total & $100 \%$ & $100 \%$ & $100 \%$ \\
\hline
\end{tabular}

Total may not equal $100 \%$ due to rounding error

9b. Has the current discussion about energy prices influenced your buying patterns, for example, do you buy more energy-efficient products than before?

\begin{tabular}{|l||c||c||c||}
\hline Response -- Buying & Total & Own & Rent \\
\hline Yes & $52 \%$ & $55 \%$ & $50 \%$ \\
\hline No & $46 \%$ & $43 \%$ & $47 \%$ \\
\hline Don't Know & $2 \%$ & $2 \%$ & $3 \%$ \\
\hline Total & $100 \%$ & $100 \%$ & $100 \%$ \\
\hline
\end{tabular}

Total may not equal $100 \%$ due to rounding error

10. Are you more concerned about the cost of fuel for your vehicle or the cost of heat for your home?

\begin{tabular}{|l||c||c||c||}
\hline Response & Total & Own & Rent \\
\hline Fuel for your vehicle & $47 \%$ & $47 \%$ & $49 \%$ \\
\hline Heat for home & $32 \%$ & $31 \%$ & $37 \%$ \\
\hline Both equally & $17 \%$ & $20 \%$ & $11 \%$ \\
\hline Don't Know & $3 \%$ & $2 \%$ & $4 \%$ \\
\hline Total & $100 \%$ & $100 \%$ & $100 \%$ \\
\hline
\end{tabular}

Total may not equal $100 \%$ due to rounding error

11. Do you think you have more control over reducing the amount of fuel you consume with your vehicle or do you think you have more control over reducing the amount of energy you consume in your home?

\begin{tabular}{|l||c||c||c||}
\hline Response & Total & Own & Rent \\
\hline Vehicle & $39 \%$ & $39 \%$ & $32 \%$ \\
\hline Home & $47 \%$ & $45 \%$ & $58 \%$ \\
\hline Both equally & $10 \%$ & $12 \%$ & $6 \%$ \\
\hline Don't Know & $4 \%$ & $3 \%$ & $4 \%$ \\
\hline Total & $100 \%$ & $100 \%$ & $100 \%$ \\
\hline
\end{tabular}

Total may not equal $100 \%$ due to rounding error 
12. If you could reduce your home heating cost by $\$ 100$ each year by having a reputable contractor install energy efficiency measures such as insulation, weather-stripping, or other low-cost measures, how much would you be willing to pay?

\begin{tabular}{|l|c|c|c|}
\hline Response Category & Total & Own & Rent \\
\hline Less than $\$ 100$ & $24 \%$ & $22 \%$ & $29 \%$ \\
\hline$\$ 100-\$ 199$ & $5 \%$ & $6 \%$ & $4 \%$ \\
\hline$\$ 200-\$ 299$ & $7 \%$ & $6 \%$ & $9 \%$ \\
\hline$\$ 300-\$ 499$ & $3 \%$ & $3 \%$ & $3 \%$ \\
\hline$\$ 500-\$ 749$ & $8 \%$ & $8 \%$ & $7 \%$ \\
\hline$\$ 750-\$ 1,999$ & $6 \%$ & $5 \%$ & $6 \%$ \\
\hline$\$ 2,000$ or more & $7 \%$ & $7 \%$ & $7 \%$ \\
\hline Don't know & $19 \%$ & $19 \%$ & $20 \%$ \\
\hline Would not do this & $20 \%$ & $22 \%$ & $15 \%$ \\
\hline Total & $100 \%$ & $100 \%$ & $100 \%$ \\
\hline
\end{tabular}

13. Suppose that for an investment of $\$ 1500$, you could be assured to save $\$ 500$ on your annual heating bill. This means that the savings would pay back the initial investment within 3 years. How likely would you be to make this investment?

\begin{tabular}{|l||c|c||c|}
\hline Response & Total & Own & Rent \\
\hline Very likely & $18 \%$ & $17 \%$ & $20 \%$ \\
\hline Somewhat likely & $29 \%$ & $30 \%$ & $28 \%$ \\
\hline Neither likely nor unlikely & $5 \%$ & $6 \%$ & $3 \%$ \\
\hline Somewhat unlikely & $12 \%$ & $13 \%$ & $12 \%$ \\
\hline Very unlikely & $29 \%$ & $30 \%$ & $24 \%$ \\
\hline Don't Know & $6 \%$ & $4 \%$ & $13 \%$ \\
\hline Total & $100 \%$ & $100 \%$ & $100 \%$ \\
\hline
\end{tabular}

Total may not equal $100 \%$ due to rounding error

Additional response information to each of the questions available from the survey by nine additional characteristics and two or more categories for each as follows:

\begin{tabular}{|l|l|}
\hline Characteristic & Number of Categories \\
\hline $\begin{array}{l}\text { Planned length of time that the } \\
\text { respondent estimates they will occupy the } \\
\text { dwelling }\end{array}$ & 3 \\
\hline Sex & 2 \\
\hline Age & 6 groups \\
\hline Region & 4 plus metro and non-metro \\
\hline Race & 3 \\
\hline Household Income & 5 plus Dual Income Household \\
\hline
\end{tabular}




\begin{tabular}{|l|l|}
\hline Household Size & 3 \\
\hline Children in Household & 3 \\
\hline Education & 4 \\
\hline
\end{tabular}

The statistical significance of the survey results decreases as the number of categories increases, which reduces the meaningfulness of the findings for the age, region, household income, and education characteristics. 


\section{Appendix B -- Benchmark Data}

The following six benchmarks compared the survey taken to the 2001 Residential Energy Consumption Survey administered by EIA. Significant differences appeared to exist in the heating fuel and household income categories. These differences may be real or:

- In the case of heating fuel, where the discrepancy was primarily between natural gas and electric heat, it is thought that the respondent wasn't sure whether the question pertained to heating fuel or all energy.

- In the case of household income, the discrepancy was primarily in the lower two income brackets, so that the survey data, when adjusted by the 'Do not Know / Did not Respond,' was closer to the EIA data.

\begin{tabular}{|l||c||c||}
\hline Own/Rent & Survey & EIA \\
\hline Own & $69 \%$ & $68 \%$ \\
\hline Rent & $27 \%$ & $32 \%$ \\
\hline Not Reported & $5 \%$ & -- \\
\hline
\end{tabular}

\begin{tabular}{|l||c|c||c|c||c|c|}
\hline \multirow{2}{*}{ Heating Fuel } & \multicolumn{2}{c|}{ Total } & \multicolumn{2}{c||}{ Own } & \multicolumn{2}{c|}{ Rent } \\
\cline { 2 - 7 } & Survey & EIA & Survey & EIA & Survey & EIA \\
\hline Natural Gas & $28 \%$ & $55 \%$ & $25 \%$ & $57 \%$ & $36 \%$ & $53 \%$ \\
\hline Electricity & $50 \%$ & $29 \%$ & $52 \%$ & $25 \%$ & $49 \%$ & $37 \%$ \\
\hline Fuel Oil & $7 \%$ & $8 \%$ & $8 \%$ & $8 \%$ & $5 \%$ & $6 \%$ \\
\hline Other & $17 \%$ & $8 \%$ & $20 \%$ & $10 \%$ & $11 \%$ & $5 \%$ \\
\hline Don't Know & $1 \%$ & & -- & -- & $3 \%$ & \\
\hline
\end{tabular}

\begin{tabular}{|l|c|c|}
\hline $\begin{array}{l}\text { Geographic } \\
\text { Location }\end{array}$ & Survey & EIA \\
\hline New England & $5 \%$ & $5 \%$ \\
\hline Middle Atlantic & $15 \%$ & $14 \%$ \\
\hline East North Central & $17 \%$ & $16 \%$ \\
\hline West North Central & $6 \%$ & $7 \%$ \\
\hline South Atlantic & $18 \%$ & $19 \%$ \\
\hline East South Central & $6 \%$ & $6 \%$ \\
\hline West South Central & $12 \%$ & $11 \%$ \\
\hline Mountain & $7 \%$ & $6 \%$ \\
\hline Pacific & $15 \%$ & $16 \%$ \\
\hline
\end{tabular}




\begin{tabular}{|l||c||c|}
\hline Race & Survey & EIA \\
\hline White & $74 \%$ & $74 \%$ \\
\hline Black & $12 \%$ & $12 \%$ \\
\hline Hispanic & $12 \%$ & $10 \%$ \\
\hline Other & $4 \%$ & $5 \%$ \\
\hline
\end{tabular}

\begin{tabular}{|l||c||c|}
\hline Household Size & Survey & EIA \\
\hline 1 & $17 \%$ & $26 \%$ \\
\hline 2 & $31 \%$ & $33 \%$ \\
\hline 3 & $16 \%$ & $16 \%$ \\
\hline 4 & $20 \%$ & $15 \%$ \\
\hline 5 & $9 \%$ & $7 \%$ \\
\hline $6+$ & $4 \%$ & $4 \%$ \\
\hline No Response & $2 \%$ & -- \\
\hline
\end{tabular}

\begin{tabular}{|l||c|c|c|c||c|c|}
\hline \multirow{2}{*}{ Income } & \multicolumn{2}{|c|}{ Total } & \multicolumn{2}{c||}{ Own } & \multicolumn{2}{c|}{ Rent } \\
\cline { 2 - 7 } & Survey & EIA & Survey & EIA & Survey & EIA \\
\hline Less than $\$ 15,000$ & $7 \%$ & $18 \%$ & $3 \%$ & $10 \%$ & $16 \%$ & $33 \%$ \\
\hline $15,000-29,999$ & $16 \%$ & $21 \%$ & $10 \%$ & $20 \%$ & $30 \%$ & $25 \%$ \\
\hline $30,000-49,999$ & $20 \%$ & $25 \%$ & $22 \%$ & $26 \%$ & $18 \%$ & $24 \%$ \\
\hline $50,000+$ & $37 \%$ & $36 \%$ & $47 \%$ & $44 \%$ & $21 \%$ & $18 \%$ \\
\hline Do not Know / Did not Respond & $19 \%$ & -- & $19 \%$ & -- & $15 \%$ & -- \\
\hline
\end{tabular}




\section{Appendix C -- Background on Survey Method}

- The survey was administered by Opinion Research Corporation by telephone to both owners and renters of residential housing and apartments.

- This report presents the findings of a telephone survey conducted among a national probability sample of 1,025 adults comprising 507 men and 518 women 18 years of age and older, living in private households in the continental United States.

- Interviewing for this survey was completed during the period October 28 - 31, 2005.

- All interviews are conducted using Opinion Research Corporation's computer assisted telephone interviewing (CATI) system.

- Completed interviews are weighted by four variables: age, sex, geographic region, and race, to ensure reliable and accurate representation of the total population, 18 years of age and older.

- The use of replicable sampling, standardized interviewing procedures, and representative weighting provides that all the surveys are parallel to one another and appropriate both for point-in-time analysis as well as tracking and trend comparisons.

- The sample is designed to be a simple random sample of telephone households that includes both listed and unlisted numbers.

- The table below shows the possible sample variation that applies to the percentage results reported -the chances are 95 in 100 that a survey result does not vary, plus or minus, by more than the indicated number of percentage points from the result that would be obtained if interviews had been conducted with all persons in the universe represented by the sample.

\begin{tabular}{|c|c|c|c|c|c|}
\hline \multirow{2}{*}{$\begin{array}{l}\text { Size of Sample on } \\
\text { Which Survey } \\
\text { Results Are Based }\end{array}$} & \multicolumn{5}{|c|}{$\begin{array}{c}\text { Approximate Sampling Tolerances Applicable to Percentages At or } \\
\text { Near These Levels }\end{array}$} \\
\hline & $10 \%$ or $90 \%$ & $20 \%$ or $80 \%$ & $30 \%$ or $70 \%$ & $40 \%$ or $60 \%$ & $50 \%$ \\
\hline 1,000 interviews & $2 \%$ & $2 \%$ & $3 \%$ & $3 \%$ & $3 \%$ \\
\hline
\end{tabular}

- Tolerances for the comparison of results from independent parts of any one survey and in the comparison of results between two independent surveys must be of at least a certain number of percentage points to be considered statistically significant. The table below is a guide to the sampling tolerances in percentage points applicable to such comparisons, based on a $95 \%$ confidence level.

\begin{tabular}{|l|c|c|c|c|c|}
\hline \multirow{2}{*}{$\begin{array}{l}\text { Size of Samples } \\
\text { Compared }\end{array}$} & \multicolumn{4}{|c|}{ Differences Required for Significance At or Near These Percentage } \\
& Levels \\
\cline { 2 - 6 } & $10 \%$ or $90 \%$ & $20 \%$ or $80 \%$ & $30 \%$ or $70 \%$ & $40 \%$ or $60 \%$ & $50 \%$ \\
\hline 1,000 and 1,000 & $3 \%$ & $4 \%$ & $4 \%$ & $4 \%$ & $4 \%$ \\
\hline
\end{tabular}

